\title{
PUBLIC ACCOUNTING IN HUNGARY. SITUATION AND CHALLENGES
}

\author{
JOZSEF SIMON \\ Simon.Jozsef@ejf.hu \\ Eötvös József College, Hungary
}

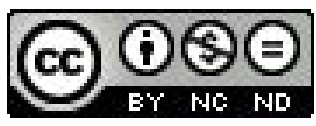

\begin{abstract}
In a democratic state, citizens expect that those currently in power be obliged to justify the way they spend and manage public funds. The enforcement of accountability has several preconditions.

At the same time, the accounting system constitutes one part of the public sector's information system. Thus, studying the information system in a systematic manner is important. The information system must meet diverse needs. The present paper aims at showing those requirements.

When considered in a comparative perspective, different public accountancy systems implemented internationally show different form. Every country can decide in which area and how the cash-flow approach and accrual based accounting can be used.

The purpose of this paper is to verify whether and how could the usage of accrual based accounting influence the public accounting methods and the functions of public accountancy.

Key words: accrual based accounting, cash-based accounting, information system, public accountancy
\end{abstract}

\section{INTRODUCTION}

From the regime changed countries of Central Europe a democratic self-government system was created firstly in Hungary, however this system supported some problems owing to the economic and political circumstances. The current political elite did not undertake to solve those problems, result from this problems have accumulated in this sector, and these have made feel negative effects. It was unambiguous that public finance, within this the self-government subsystem stands in need of reform.

In what follows I analyse the problems of Hungarian public finance from the point of view of local governments. This study examines each single main point of the reform. In this paper, I deal with the system of settlement and recording of accounts.

One hypothesis of this paper is that the system of settlement and recording of accounts does not fulfil the essential requirements of management. This situation is caused by some simultaneously occurring factors. The obligations of settlement and report of accounts by local governments are regulated by several laws, all of which together do not form one homogenous system. Therefore, local governments cannot understand those laws. Such a regulation is not useful for effective management because under existing conditions registered information is completely different from the claims of management. Local government management is 
made unviable by cash-based accounting. Self-governments do not have enough information to set an annual budget.

In such situations, the reform of public finance requires two things, political will and renewed regulation frameworks, both of which must have professional bases. The key points of the regulation reform are the transition to accrual based accounting and the maintenance of a cash-based principle in those areas. It is necessary to make use of accrual based accounting because it has any advantages.

\section{CHARACTERIZATION OF HUNGARIAN LOCAL GOVERNMENTS' SYSTEM OF SETTLEMENT AND RECORDING OF ACCOUNTS}

\section{Regulation of the law}

Accounting obligations of Hungarian local governments are regulated by two legal documents. These are the law of accounting and the $249^{\text {th }}$ governmental regulation from 2000. The latter is actually based on the law of accounting. Its rules are interpreted in relation to the public sector. There is another not negligible problem that the application of the above mentioned rules is not only restricted to local governments, but the knowledge of these poses a considerable challenge. Those experts who are frequent visitors to business accounting expound the currently used accounting regulation as a prescribed requirement for management of local governments. According to their opinion, the present accounting system cannot support the management processes of self-governments.

Self-government's book-keeping by double entry has a special solution, that is, the so-called method of cash-based accounting. They use this method to settle accounts, to plan budgets, to evaluate management performance, to draft budgets and to develop strategies for future plans for all areas of management. Cash basis accounting means that only those economic transactions which appear as real outgoings and incomes in a financial sense can be taken into account. Because of cash-based accounting, the cost concept cannot be effective and in relation to the income provisions cost are not a fit measure of management's economic efficiency. Expenditures are equal to costs so transaction must reckon them as used at the moment of expenditure. Similarly to expenditures, income provisions and notices for pay cannot keep accounts. Such transactions appear in the accounting system if they come to hand on the basis of announcement of the treasury or account managing bank. A further feature of accounting rules of local governments is that recording of incomes and expenditures means the fulfilment of income and expenditure provisions.

\section{Cash-based accounting - the vehicle of wasting}

It is a deep-seated belief that the application of cash-based accounting is classified as neither a bad or good practice in itself. The evaluation of this concept depends on some qualifying conditions. Owing to lack of these things, it can be said that the cash-based accounting method does not meet the expected requirements. We should examine the main causes of this statement.

One of the objectives of the accounting system is to provide reliable and real information about the property and financial and income-outgoings situation of the 
local governments, as well as its ability of income making and result of management for principals of local government, other administrative bodies, creditors and investors (Kara, Kusztosné, Varga, 1992, p. 45). Additionally, the accounting system controls and records management transactions, and the occurred change in financial situation then it takes into account in logical closed system, sums up, controls and analyses documented transactions (Nyikos, 2005). So one of the principal questions is who the involved people in the accounting system are. Another question is how and what methods can produce relevant information for participants.

Interested persons can be divided into two groups: the decision-makers and "other interested" persons. The former group can further be subdivided into two groups: politicians, who make political decisions, and executives, who are responsible for the local government's tasks. The requirements in relation to the accounting system of these two groups are different. The aim of politicians is to decide how to allocate annual budget receipts so that the expectations of inhabitants can be satisfied for the most part. Resulting from this, expectations against the accounting system are restricted to the financial resources.

Cash basis accounting is suitable for politicians' requirements. To make the balance sheet about cash-based information suits to cabinet because accomplished expenditures are recorded in the intended structure, so it shows that the plans of the cabinet come true. As well this method offers the practise that Cabinet can give account of completed expenditures in such structure and decomposition which is the most favourable for it. In my view, this kind of reasoning is only partially true. The above mentioned political interests should dominate only over a short period of time, for example, within one year.

On the contrary, the requirements of the executive body are more complex than the expectations of politicians. Responsible for executing political decisions, the executives can express opinions about the quality and efficiency of local government management. They face a discrepancy between poverty of resources and short-term tasks. It is also true that conflicts culminate at the stage of budget planning and the budget approval process. It figures as lack of financial resources so as a liquidity problem. However, a fine combination of incomes and expenditures does not ensure that the expenditures of public funds are rational or not. The application of cash basis accounting in Hungary in its current form can hardly satisfy such requirements. This statement can be verified with some arguments; the most important factors are the following.

Results of the basic principle of cash basis accounting liabilities and debtors do not appear in the book-keeping. Therefore, one of the most important accounting principles cannot be effective. Self-governments ought to decide to carry out those transactions on separate analytical accounts, but this solution is not the most optimal because of two factors. On the one hand, recording of an account means additional costs; on the other, the information (for example change in cash-flow, liabilities and debtors) are out of the recording system. These problems cumulate as the time go by. Certainly, those accounts carry important information because the real financial balance can be defined only if there is a consensus to take into consideration those record types. It seems that local governments should increase 
their debtors with impunity, at least in the short run, until the financial realizations of those transactions do not come true.

In the book-keeping the economic meaning of depreciation does not come true. It is determined for local governments what sort of depreciation rate must be used for different types of property, but the depreciation does not make a change in cash-flow so it should not settle accounts. If amortization is not included in the book-keeping, for local governments there is no interest to maintain the balance between the real market and book value of assets. This indifference is the main reason why the market and the recording value of local government assets break away from each other and, eventually, results in property management being stuck in a hopeless situation. Among others, management of local governments cannot state precisely the replacement time of assets and by selling the selling price will be behind the market value. The quality of providing of local government's tasks has not any guarantee because of problems of the property management.

According to the cash-flow approach, it cannot be determined, how much the providing of a task is the duty of a local government. Public services are provided by spending of public funds. But the public services are, on the one hand, realized from the budget of previous year and, on the other hand, from public incomes of this year. Resulting from the basic principle of the cash-based accounting some transactions get into or fall out of records. But they weigh on the budget of this year. Local governments can estimate the real cost of tasks on a large scale, but it is only an estimation, which is a time and money-consuming process.

Without knowing the full cost of a task, local government principals cannot make a decision regarding the optimal organizational framework of providing of task. Supplying services are, then, provided by companies or public institutions. Lack of information about the full cost means that the management of a local government cannot be effective. Strictly speaking, the attitude of an owner and the attitude of an investor cannot be in conformity because the evaluation of management is not doable with the cash-flow approach.

Furthermore, the cash-flow approach gives an opportunity to address some of the problems of management: how to operate the control system; whether it can present processes as truthful if they are unreal; whether it can hush up the problems; or whether transparency can become to invisible thing. In my opinion, an internal audit carries out the classification of local government's management about the laws in the first place. With regard to the settlement and recording of accounts for local governments, it should modify the laws. It can be that the internal audit gives an excellent rate to the management of a local government but that management is wasteful. If the annual budget and report is based on the principles of cash-based accounting, then the principle of reality cannot be effective and the defined breakdown of report hinders the extrications of restricted information content. This gives such a situation, in which the annual report will be always static. This situation is caused by financial difficulties.

To sum up, the present applied accounting system by local governments cannot fulfil the requirements of self-government principals; cash-based accounting is not the best solution for the expectations of management. The required infor- 
mation for decision making is either restricted or does not exist. So principals of local governments find themselves in a hopeless situation, we cannot verify the efficiency of public funds.

Up to this point, I examined the relationship between the activities of decision makers to the expectations of management. So far, my conclusion is that cashbased accounting in Hungary is not suitable for the public management.

However, the most important and most involved persons are the inhabitants, and they get less and less exceptable information. We can rank other companies which are in contact with local governments and banks to the group of other interested parties. Nowadays, the attention of banks brings into focus the creditworthiness of local governments because of indebtedness of this sector, and the main purpose of banks is to cover the credit demand and gain a good debtor. In the past 18 years, banks did not think about the types of collateral against the credits of local governments. Such an attitude is reinforced by a famous slogan, that "if local government cannot sink its credit then government helps." After that, it turns out that two thirds of local governments cannot provide their tasks from their own resources, and they require to be subsidised. The central budget does not have the obligation to give consent concerning local governments' credits. The long-term obligation of local governments increases constantly. The present applied settlement and recording of accounts, so balance sheet, cash-flow statement and operating income statement of public sector, are not be able to classify loan applicants. These documents could not show the financial capacity of local government.

\section{CLAiMS OF DEVELOPMENT}

Information needs of interested people can be satisfied with a well functioning accounting system. This need for information is valid not only by the local governments but in the whole public sector. The most important problem of the present regulation is that the book-keeping and the practice of report making are cash-based which does not serve the claims of local governments' management. For this reason, information is not true, and is can lead to wastage, and naturally wastage in management.

The accounting system in the public sector and supplying of data in a prescribed structure serve the budget planning well or poorly. Clearing of accounts with public funds, and this process is followed by an external and internal audit system (Kassó, 2000). The accounting system and within this the book-keeping changes self-contained in the practice of public sector's management, in actual fact it does not perform any feedback function. In addition, that it does not serve the collection process of the actual budget and the management practice; still, it does not give information for electors and economic partners. This situation began in 1992, when the Hungarian Parliament passed the law of public finance, in which it is determined that the public sector uses the cash-based accounting method for book-keeping. The real situation deepens with the low quality of accounting documents. The accounting reports contain some fictional information. Reporting documents are similar to the business sector reports: they mislead some readers. In practice, it occurs often that 
outsiders, namely, banks and investors, form the standard financial indicators from the balance sheet and the operating income statement of local governments (Nagy, 2004.) On the basis of all this, it can be verified that the public finance and the accounting system of local governments require reform. In this process, all temporal delays cause losses not only for the central budget, but for all Hungarian citizens in general. The modernization process has two conditions: one is the political will, by which I mean that the information system shows the truth and the full situation of management excluding any manifestations of manipulation. The other precondition is the existence of a suitable development strategy. In what follows I expose the latter point, which is made up of three logical parts: (1) the introduction of basic methods of accounting system; (2) the recommendations of specialist literature and international experience, and, finally, (3) the synthesis of these points. In this situation, what kind of development strategy should be suggested and what should be the main points of this program in Hungary?

\section{Introduction of basic methods of accounting system}

The first and most important question concerns the composition of the development program: what sort of basic methods can be applied by different countries in the public sector. Nowadays, the accounting system of the public sector is based on two concepts: one is the above discussed cash-flow approach, and the other is the accrual based accounting. Practice shows that these principals appear in parallel with the accounting system of the public sector almost in all countries. Namely, those countries use in certain areas of the public sector the cash-based and other areas the accrual based accounting by recording of accounts. On the basis of this, we can distinguish two so called "clear methods," those that use the corrected, accrual based accounting or the corrected cash-based accounting method. To sum it up, the essence of the corrected, accrual based accounting method is that the public sector applies henceforward the cash-flow approach on predetermined areas of management. The selection of these areas occurs according to their importance in the management processes. The cash-based accounting means that the settlement of certain transactions can diverge from the realisation condition. For example, some transactions do not appear in the book-keeping, although they have materialized in cash-flow change in management (Kassó, 2000).

Contrary to the cash-based accounting, transactions appear in the book-keeping not on the date of change in cash-flow, but at the moment of theoretical realization. The realization date must be determined for all transactions. For example, this date could be the date of claim's acceptance or the date of allocation, or the moment when a citizen obtains the claimed sum. It is clear, then, that fixing of realization date is subjective, and what results from this is the determination method that can influence incomes and expenditures, so the sum of balance of a period of time. We should emphasize that the date of expiration must be determined in accordance with economical expediency and principle of true overall picture and this method must be enforced consistently. One large advantage of this method is that liabilities and debtors get into the settlement and recording of accounts system in full scope. In this way, local governments should not re- 
cord other systems for estimation of these shadowing factors. With the knowledge of liabilities and debtors, as well as the real balance of management, the deficit (often) or the surplus (rarely) is derived explicitly and the most significant thing is that there is no opportunity for an autocratic influence of facts and figures. On the basis of this, a chartered accountant can verify with the aid of a professional audit activity that data are true or not, and whether public funds have been spent on behalf of predetermined purposes or not, and spending was effective or not. Contrary to the cash-based accounting, the accrual based accounting can manage the consequences of depreciation, and annual losses of value of assets appear in the book-keeping explicitly, too. It thus transmits a clear message to the principals: according to this value of a given asset decreased, and somebody must create the necessary funds for replacement of this asset. The cost of using an asset is built up in providing the cost of public services. Pricipals could cover these costs from different sources, by optimal case from any charges, regrouping from other areas of management, or some kind of subvention.

\section{Recommendations of specialist literature and international experience}

Characteristics of the public sector have changed radically over the last few decades. The crisis of the concept of a welfare state came about the year of 1980. At this time the functional concept of the public sector began to appear. This ambition concerned all sectors of public administration in almost every country, including the subsystem of local governments, too. To examine this process from the point of view of local governments, it can be concluded that all the three essential components of management have changed radically, namely the types of provided services, the methods of supplying goods and services, and the sphere of concerned people who make use of public services. In consequence, it is perceptible that the earlier sharp dividing line has melted away between public and business sector. Simultaneously, it means that competition has gradually gained ground in the public sector, with all its positive and deleterious effects. Local governments must facilitate the process of modification of environmental characteristics, just like in the past. Derived from this countries different methods have applied different methods in favour of reaching of this aim, but this method has some common features (Reichard, Bals, 2001).

The principle of the transparency and the audit of management have become basic requirements for the public sector in all European countries. Citizens have a right to expect that their local government can reckon with spending of public funds. Local governments must demonstrate to citizens that using of public funds was effective. With these two principals it is in close connection with the principals of efficiency, which is mentioned in specialist literature as the value for money theorem. So not only is it important whether spending of public funds was lawful or not, but also if local governments can achieve the set goals or not. In the majority of countries, decentralization plays an important role, and the significance of the role of decentralization depends on the type of state organization. Decentralization means that some tasks should be undertaken on a medium- or local level and not by central governmental units. We can find shifting of accent in budget planning because budgets are based on the output rather than the input aspect. 
In conclusion, these factors we can verify if the main purpose is the development of public sector's competitiveness. According to various experts, such a goal can be realized in different ways, and resulting from this statement a number of methods were devised to solve this problem. If we were to look at the latest tendencies, it is the most significant aspect of New Public Management (Sight, Bowerman, 1998; Broadbent, \& Guthrie, 1992; Lapsley, 2008; and others). One assumption of this aspect that the public sector's competitiveness can develop in that way only if that sector adopts the accrual based accounting method, which is used by business organizations. The literature does not adopt a common standpoint. Experts represent three viewpoints. According to the first group of experts, the accrual based accounting does not involve solving the problem of the public sector because of the specific characteristics of this sector. The most often raised argument is the rejection that public institutions are not profit-making a contradiction to the business sector (Jones, \& Puglisi, 1997; Olson et al., 1998; Matheson Kwon, 2003). The second group claims that the adoption of accrual based accounting is necessary for modernization of the public sector and its development can bring some positive effects in management (Shand, 1990; Rhodes, 1998). The experts belonging to the third group believe in the adoption of accrual based accounting, but they think the new method should be introduced only in the case of some areas of management (Barton, 1999; Christiaens, \& Rommel, 2008). Adoption of new accounting method is supported by some international organizations. From these institutions the most important is the IFAC, who prepared the international accounting standards (IAS) for the public sector and it makes studies and comparative papers about the public sector's accounting system of countries of the whole world.

The adoption of accrual based accounting in practice shows a different picture. Individual countries declare other principles concerning the measure required for the adoption of the new accounting method.

We can classify countries into two groups. The main characteristic of the first group is that they mostly use the cash-based accounting and use accruals only within some selected areas. The other group applies accruals very often. But there is some difference between these two groups. For example, they differ in terms of the degree to which they use this method.

The process of adoption of the accrual based accounting is in progress, but it advances very slowly, which is due to various factors. It seems that the most important problem is that it does not eliminate all antipathies of adoption of accrual based accounting. There are some areas, in which it should change in favour of success. We can reckon among these areas for example the improvement of financial management, the development of information flow towards politicians, the better deployment of available information, the understanding of international accounting standards, the setting of local requirements, the training of accounting employees of public sector and the exploitation of the information system. Reports about those top countries in a state of uncertainty those countries, which are planning the adoption of accrual based accounting system. The adoption of a new accounting system does not come true because of problems of adoption of top countries or the necessary conditions for such an adoption. Of the discussed 
former preconditions, we should emphasize the political will, which is the basic condition for that process to occur. Furthermore, every country which plans the adoption should design its own development strategy, so that they must make a number of decisions, for instance, about when to begin using an accrual principle; in which areas of management the accrual based accounting should be applied. To succeed in adopting such an approach, we need to organize courses for accounting specialists and we need to reconstruct the accounting policy.

\section{CONCLUSION}

The Hungarian public sector requires reform. One element of this should be the improvement of the accounting system. Importantly, it should not to be adopted without taking note of the characteristics of the Hungarian public sector and international tendencies. The development concept can be defined according to a combination of these two factors. This concept should be feasible. Also, it should bring about the anticipated optimal effects for local governments and for other levels of public sector.

In Hungary it is pointless to debate over which accounting method the cash-based or the accrual-based is most suitable for the public sector. Undoubtedly, this problem is embedded in a wider problem area; it is the efficiency of public sector. The following problems still need to be solved: the unambiguous defining of state tasks, the optimal distribution of tasks among the state levels, the rational determination of the circle of tasks and jurisdictions connected with a state level, the constitutional reform of public administration, the reform of management's regulation and the complex improvement of financial system of local governments. The handling of these problems is of vital importance.

According to the international examples it is impossible to set an objective of full adoption of accrual based accounting in the Hungarian public sector because now preconditions do not exist. But this does not mean that there is no opportunity for the development of the public sector, international experience certifies that the most appropriate field for adoption of accrual based accounting is the local government system, surely it is possible to test the new different accounting methods "on a small scale", and there is more possibility to change methods if such a need arises, and moreover the accumulated experience would be expandable later to other levels of the public sector.

In my view, it is useful to sketch out two phases of the development strategy of the Hungarian local government system. The first period will last until all important conceptual problems are solved. The characteristic of this period is that the accounting system is based on the cash-flow approach, but the new slogan reads: "Do it more effectively." It means that it must assure the suitable administration of available information, recording of liabilities and debtors must be up-to-date, by financial allocation it must concentrate on tasks and not on institutional aspects and Appropriation Accounts must have a logical structure. In the first phase of modernisation, the adoption of the accrual based accounting system can come to the fore. It is worth considering in which areas the accrual aspect should be applied. 
The public sector in Hungary requires modernisation; the starting date of this process is not postponable for ever. In this process, the public sector should reconsider the basic rules of operation, and it is thus very important for politicians and the reigning political power to become conscious of the necessity of reform. They must embark on planning and realizing development strategy having first consulted with the interested people. It is essential to underline that the adoption of accrual based accounting be well-founded. The introduction and the productive application require a number of years in accordance with optimistic estimates.

\section{REFERENCES}

Barton, A. (1999). Public and Private Sector Accounting - The Non-Identical Twins. Australian Accounting Review, Vol.9, No.2, 22-31.

Bowerman, M., Ball, A., \& Francis G. (2001). Benchmarking as a Tool for the Modernisation of Local Government. Financial Accountability \& Management, Vol. 17, No. 4, 321-330.

Broadbent, J., Guthrie, J. (1992). Changes in the Public Sector: A Review of Recent "Alternative" Accounting Research. Accounting, Auditing \& Accountability Journal, Vol.5, No.2, 3-31.

Christiaens, J., Rommel, J. (2008). Accrual accounting reforms: only for businesslike (parts of) governments. Financial, Accountability E Management, Vol. 24, No. 1, 59-75.

Jones, S., Puglisi, N. (1997). The Relevance of AAS29 to the Australian Public Sector: A Cause for Doubt?. Abacus, Vol.33, No. 1, 115-132.

Kara Pál-Kusztosné-Varga S., (1992). Economical basis of local governments, Budapest: Agrocent Press.

Kassó, Z. (2000). Az államszámvitel fogalma, feladata, lehetséges megoldási módjai [Concept, tasks and feasible methods of the public accounting]. Kézirat: IGE Kft.

Lapsley, I.(2008). The NPM agenda: Back to the future. Financial Accountability E Management, Vol. 24, No. 1, 77-97.

Matheson, A., Kwon, H.S. (2003). Public Sector Modernisation: A New Agenda. OECD Journal on Budgeting, Vol. 3, No. 1, 7-23.

Nagy, K. (ed.) (2004). Az önkormányzati adósságregiszter kialakításának megalapozása [Foundation of local government registry]. Retrieved from http:/ / www.onkormanyzati.hu/ar_tanulmany.pdf

Nyikos, L. (2004). ). Az államszámvitel fő kérdései a jelenlegi időszakban, Magyarországon [Actual main questions of public accounting system in Hungary]. Retrieved from http://www.attentus. hu/Local\%20folder/Tanulmanyok/allamszvitel.pdf

Olson, O., Guthrie, J., Humphrey, C. (1998). Growing Accustomed to Other Faces: The Global Themes and Warnings of Our Project. In: O. Olson, J. Guthrie, C. Humphrey (eds.), Global Warning! - Debating International Developments in NewPublic Financial Management (pp. 435-466). Oslo: Cappelen Akademisk Forlag.

Reichard, C., Bals, H. (2002). Resource-based Accounting and Output - Budgeting as Common Patterns of Public Sector Financial Management Reforms. Proceedings of the 3rd International Public Sector Management Symposium Baden Baden, 137 - 151.

Rhodes, R. (1998). Different Roads to Unfamiliar Places: UK Experience in Comparative Perspective. Australian Journal of Public Administration, Vol.57, No.4, 19-31.

Shand, D. (1990). Australia Moves to Accrual Accounting: Problems and Prospects. In: J. Forster, \& J. Wanna (eds.), Budgetary Management and Control: the Public Sector in Australasia (pp. 142-150). Melbourne: Macmillan. 